\title{
SOCIAL ENVIRONMENT OF HIGHER EDUCATION ESTABLISHMENT AS A SYSTEM-FORMING FACTOR OF PROFESSIONAL SOCIALISATION
}

\section{Shaposhnykova I. V.}

\section{INTRODUCTION}

Postindustrial society attaches great importance to human capital, now it is more significant than natural resources and accumulated wealth. Person's abilities, his knowledge, skills in the conditions of new geopolitical and socioeconomic challenges are recognized as an asset for regular enrichment. The modern labor market is characterized by high competitiveness and significant dynamics. The available approaches to specialists' training do not allow higher education establishment graduate students to integrate with modern labor market requirements effectively. The low level of specialists' competitiveness and the necessity of their rapid integration into the corresponding profile of economic activity conditions predetermine the need for a radical revision of the system itself. At the same time, the quality and content of the students' curricula are secondary. At the forefront are issues of young specialist social maturity formation.

The solution to this problem is multidimensional, because modern world is characterized by a number of complex and contradictory social processes that not only changes the very social role of the of Educational Institution, but also social practices and mechanisms of human interaction. The multidimensional nature of the problem determines a wide range of researches, including related to the problems of youth socialization, its cultural formation, capitalization of acquired knowledge, and also related to the analysis of the contemporary value and normative status of native students.

This problem arises in two aspects: ontological and epistemological. The first one outlines the need for a specialist with a certain set of social, psychological and professional characteristics for a relatively long time, while the requirements for a particular type of professional activity are constantly changing. In fact, we are talking about a social modeling of the internships nature, adequate to the changing conditions of the information 
society. The second aspect, which provides a scientific explanation of the professionalization process' reasons and nature while studying in the higher education establishment, is rather fragmentary and requires systematic expansion and rethinking.

Therefore, the research relevance of the professional development and formation process is a simultaneous study of the individuals' capitalization selfish goals mechanism implementation and adaptive mechanisms of effective integration into the labor process' changing conditions. In fact, there is a public need to find out the possible variations in the process of professional formation and their reduction in accordance with the specific social and production conditions of the future specialist functional responsibilities.

Analyzing the professional development process from the point of various scientific fields, it should be noted that this development is quite systematically analyzed by different philosophical and sociological schools. So from a philosophical point of view, the study of the professional formation process is connected with the man entry into one of the basic spheres of human existence (the labor sphere). As a philosophy category, labor is a form of human world reflection, both physical and ideal. In this context there is a need to integrate these two aspects in a specialist- forming process. From the sociology of education point of view the attention should be paid to the aspects of the knowledge formation among university students as well as the process of social consciousness changes regarding the capitalization of graduates with higher education. In terms of labor sociology the scientific interest is the definition of a direct behavioral acts' nature that should be developed in students through education in accordance with the changing conditions of the labor process. Current issues of professional development arise in the context of future specialist further capitalization and management process during his employment.

\section{Higher educational institution as a professional socialization environment}

Getting sociological theoretical understanding of education quality and the individual's professionalism was described by classics, including E. Durkheim, M. Weber, G. Spencer, P. Sorokin, T. Parsons, K. Mangayym, G. Becker, T. Schultz. The problems of youth as a subject of social development are paid to the attention of such world-famous scholars as: 
E. Durkheim, R. Merton, T. Parsons, P. Sorokin. Consideration of cultural aspects of the professional formation (philosophy of life) - M. Haydegger (phenomenological aspects of the culture formation). In the process of interpreting social and cultural practices the great values are acquired by S. Freud, K. Jung (Freudism, Neo-Freudianism), M. Fuko, D.F. Liotar (structuralism and post-structuralism). The great importance in the study of educational process social and cultural aspects has the works by A. Zdravoimyslov, N. Skvortsov and others.

In the context of this study, higher education is seen as a factor in adapting to the individual's living space. This problem was investigated in social and philosophical writings by Yu. Habermas, O. Spengler, P. Berger, T. Lukman, A. Turin and others. Consideration of the social space as a medium of human interaction is found in the writings of G.Zimmel, P.Sorokin, P.Burdieu.

As professionalization is a part of personality forming process, the works by V. Lisovsky, A. Kovalyov, V. Yadov are studied. They examined aspects of socio-economic, spiritual and other aspects of personality formation.

General theoretical and sociological approaches to educational problems studying, its functional characteristics and values in public life are presented in the works of foreign and native scientists: I. BestuzhevLada, M. Rutkevich, F. Sherega, V. Ossovsky, E. Yakuba, etc.

The work of A. Onisimov, A. Osipov, E. Klimov, V. Shadrikov, A. Saveliev and others is devoted to the sociological model of a university graduates' formation.

A. Zdravomyslov, Zh. Toshchenko, G. Zborovsky, G. Cheredinichenko and others made a significant contribution to the study of individual's socialization and professionalization.

Among the famous researches a number of well-known scholars also worked on development and management of higher education including V. Astakhov, I. Gavrilenko, V. Gorodjanko, O. Skidin, M. Lukashevich, M. Rutkevich, V. Chepak, D. Shvets and others. The diversity analysis of the student youth social practices is devoted to a large number of works by our sociologists as: L. Aza, V. Arbenina, V. Bakirov, E. Golovakha, S. Makeev, B. Nagorny, V. Nikolaevsky, N. Pobeda, L. Sokuryanskaya, S. Oksamitna, L. Khizhnyak, A. Yakuba.

Despite considerable sociological developments in the field of professional development of young people, there was not enough 
attention paid to the issues of socio-technological aspects of the students' professionalization in the process of their training in higher education establishment.

Modern scientific sources include consideration of the "professionalization" category mainly to the psychologists' attention. In this case, this approach essentially narrows the problem field and does not allow establishing causal relationships in the process of professionalization between the individual and the reference group. The psychological approach determines the object-subject one to the consideration of the professionalization problem while, in our opinion, it should be correctly to discuss the subject-subject logic of the professionalization process.

The sociological sources also contain approaches to this phenomenon studying, however, for the most part, professionalization is appreciated from the valuation position. In our opinion, the modern pace of socio-economic processes determines the attention to the instrumental component of the process of professionalization, namely, the phenomenon of professionalization should act as an object of social design. We believe the current pace of socio-economic processes determines the attention to the instrumental component of the professionalization process - the phenomenon of professionalization should act as an object of social design.

Category "professionalization" is often used in scientific research literature to analyze problems of professions and professional activities, which is considered as an individual's specific condition. The term "professionalization" appears in the dictionary of the Ukrainian language, which is defined as the process of "mastering by any profession as their regular occupation; transition to professional ranks by which position causes a status, adequate remuneration and privileges." 1

A substantially different definition of the term "professionalization" is proposed in another encyclopedic dictionary: "a holistic continuous process of a specialist personality formation, beginning with the time of the future profession choice, and ending when a person ceases active labor activity." 2

${ }_{1}^{1}$ Словник української мови: в 11 томах. - Том 8, 1977. - Стор. 332.

2 Душков Б.А., Королев А.В., Смирнов Б.А. Энциклопедический словарь: Психология труда, управления, инженерная психология и эргономика / Б.А. Душков, А.В. Королев, Б.А. Смирнов. - «Академический проект, Деловая книга», 2005. - 848 с. 
Taking into account that social processes that take place within the higher education studies framework are aimed to form a student's professional readiness for a wide range of functional responsibilities, one should more clearly distinguish approaches to socialization and professionalization.

According to E. Durkheim the process of socialization is an "every minute feeling of ... the pressure of the social environment by the child, which seeks to form it in his way and has parents and teachers as his representatives and intermediaries." ${ }^{3}$ So, the artificial process of professional competence formation will coincide with socialization.

Another researcher, E. Erickson, imagined, with one hand, successful socialization as the process of acquiring the typical features that characterizes a society in which individual functions. On the other hand - giving a particular type of behavior by individual characteristics. E. Erickson "understood socialization both as an individual, and as a collective process, which is largely occurs through the mechanism of identifying the individual with the group, people, society.

Identity points to the involvement of the individual in the unique values of the people generated by his unique history, but this is the only one of a broader concept of the human life cycle, according to which socialization is a consistent process of individual deployment through known phase-specific psychosocial crises." ${ }^{4}$

Thus, the instrumental difference between socialization and professionalization in the process of a professional personality forming during his training is minimal. However, in order to identify the differences, we consider it expedient to continue the analysis of existing approaches.

Given the findings of the researcher V. Mansurov professionalization process is seen by the representatives of the sociology functional direction as a professional group's response to the needs of society. ${ }^{5}$ We consider it possible to further use the above thesis as a

3 Дюркгейм Э. Социология. Ее предмет, метод, предназначение / Пер. с фр., составление, послесловие и примечания А. Б. Гофмана.- М.: Канон, 1995.- 352 с. (История социологии в памятниках), с. 34.

${ }^{4}$ Рюль В.О. Дослідження феномену соціалізації в наукових концепціях розвитку особистості / В.О. Рюль // Науковий вісник Ужгородського університету : Серія: Педагогіка. Соціальна робота / Гредкол.: Козубовська I.В. (гол. ред.) та ін.]. - Ужгород: Видавництво УжНУ «Говерла», 2011. - Вип. 23. - С. 150-154. - Бібліогр.: с. 154.

5 Профессиональные группы: динамика и трансформация / Под ред. В.А. Мансурова. - М.: Изд-во Института социологии РАН, 2009. - 419 с. с. 22. 
dominant one, basing on the analysis logic principles of functionalism. However, the needs of society are also a very discrete. It demonstrates the inability to adapt professional future (in the process of professionalization) to the needs of society. Adaptation to the requirements of specific (target) groups is more correct.

Considering professionalization in the broad sense, we should refer to P.Sorokin's works. He outlined the channels of vertical mobility such as the army, the church, educational establishments (school), government groups, political and professional institutions, organizations which create the material values and the family. ${ }^{6}$

Professionalization is an integral factor of social mobility in each of the channels, since it capitalizes a graduates of a higher school on social needs at the present stage of social development, except the last social institution. Proceeding from the proposed logic, it is not the affiliation to a particular channel (participation in it), but social readiness (professionalization) ensures the social mobility. On the other hand, according to some authors, professionalization is a factor of mobility constraints. In our view, the existence of a connection between professionalization and social mobility predetermines the possibility of its content establishing different from the process of socialization. The essence of this difference is that socialization is a successful integration into a particular community (group) in order to ensure stability in society. In contrast, professionalization is a condition of social mobility, which, being similar to socialization by forms of influence on the individual, has fundamental differences in the social system.

Thus, the formation of an expert and the individual are closely connected. The formation of a professional/ expert is considered by some researchers as one of the developed forms of the individual in the unity of professional development and personal qualities in which the individual fixed idea about the ability of a particular activity.

It is clear that there are certain professional individual abilities regarding the functions of a certain type. In this sense, the individual (psychological) abilities, supplemented by the social ones, lead to the formation of a professional. The process of such an addition should be

6 Сорокин, Питирим Александрович. Человек. Цивилизация. Общество / Питирим Сорокин; [Общ. ред., сост. и предисл., с. 5-24, А. Ю. Согомонова]. - М. : Политиздат, 1992. - 542, [1] с.; 22 см. - (Мыслители ХХ века. Редкол.: Т. И. Ойзерман (пред.) и др.). 
objectified through a system of social institutes, one of which is the Institute of Education. In our view, it was its role in the professionalization of the individual is crucial, because the structure of the social institution begins targeted social impacts on the individual, during which his psychological competence to further the process of professional development are formed.

In view of the above, we believe that it is fundamentally important to proceed also from the psychological preconditions of the individual at the initial stage of professionalization, in particular:

a) every person, according to his individual qualities, first of all, with professionally significant abilities, most suitable for a limited range of occupations (professional functions);

b) professional success and satisfaction with the profession is determined by the degree of individual qualities conformity to the particular profession requirements;

c) professional choice is essentially a conscious and rational process in which an individual determines a personal disposition of psychological or physical qualities and correlates it with existing dispositions obtained during the other professions testing.

Closing basic principles of the professionalism and consideration in the process of basic psychological characteristics of the individual allows to specify the "professionalization" as individual life strategies. Thus, professionalization strategies, under which foreign researchers understand the group's upward mobility ${ }^{7}$, provide conditions for the implementation of individual policies rising.

Thus, the process of professionalization during university studies is a preparation to the process of entering into specific social roles, due to vertical hierarchy and professional workforce.

As T.Parsons noted, the professional roles outlined by typical careers vary substantially every time they move to a new career stage. It is here the one of the most important problems of adaptation related to the career beginning arises: in particular, from the low responsibility position, which becomes more and more accountable. The situation is changing, the person submits many at the beginning, and then becomes the manager of many people. It is known that such changes cause very severe stress,

${ }^{7}$ Профессиональные группы: динамика РАН, 2009. - 419 с и трансформация / Под ред. В.А. Мансурова. - М.: Изд-во Института социологии. 
but the fact remains that most people successfully overcome it without going through a complex process of learning ${ }^{8}$.

Thus, the role of an educational institution in the process of professionalization is fundamentally high, and the expediency of attention from social and technological positions is virtually indisputable. The above creates the preconditions for the formation and implementation of specific social programs and projects aimed at intensifying the process of professionalization in the social environment of higher education establishment at different levels, and is also a significant factor in the capitalization of the future professional.

\section{Professional self-determination in the labor socialization system}

The personal and professional formation of Ukrainian youth takes place in the difficult conditions of socio-economic transformation of society.

In the transition period there was a fundamentally new situation in which young people make their professional choices basing on unsteady occupational structure, lack of job security and the need to compete in the labor market. The above imposes a significant impact on professional choice logics. However, the most significant social processes that transform the choice of professional activity of contemporary Ukrainian youth can be:

Firstly, that there is an intensification of social differentiation, the emergence of "rich" and "poor". The more active this interaction develops in society, the more influential financial status becomes. It determines the level of harassments, educational and professional intentions and youth life strategies.

Secondly, market transformation have led to hopping popularity of new professions that serve the market economy (manager, advertising and lending specialist, banker), partly due to the public attention to entrepreneurship.

Thirdly, the formation of active youth self-determination, independent choice of professional activity and funds investment in obtaining a profession takes place as a result of the state refusal to control the sphere of professional guidance. Relevant processes are inherent not

${ }^{8}$ Парсонс Т. О социальных системах / Под ред. В.Ф. Чесноковой и С.А. Белановского. - М.: Академический проект, 2002. - 832 с., с. 350-351. 
only for young people who first acquire education, but also for those who are focused on continuous retraining. However, in this case, the risk of error in professional choice and material loss increases.

Fourth, the lack of centralized planning and redistribution of graduates complicates the process of young professionals' employment, which negatively affects the vocational guidance process, but at the same time increases its importance, since the correct choice of profession, taking individual abilities, significantly increases the chances of effective competition.

Fifthly, the lack of priority sectors of the national economy development, the crisis of leading industries, and the under financing of science, culture, education creates difficulties in professional selfdetermination because of the difficulties in understanding promising professions (specialties).

Market and postmodern transformations have caused the displacement of the young generation values, including the value of labor. Work began to be perceived by young people as instrumental value "source of income". This installation reflects the formation of a new "market" labor and consumer ethics. Such ethics does not contain, in our opinion, a fundamental negativity, but its formation as a holistic cultural phenomenon requires a certain period of time longer than the one that has passed since the independence of Ukraine.

Realizing this, it is relevant to study the features of modern students as a social group, its problems and the degree of professional choice awareness. Given the social significance of this group, the solution of the outlined problem can be illuminated by analyzing the formation mechanisms of students professional orientations and thus become an important theoretical and informational basis for determining the optimal ways of its primary labor and further professional socialization in the system of higher education, as well as the implementation of the initial stage of such socialization - provision of youth professional guidance (both in the process and before the beginning of education in the university).

The solution to this problem led to the organization and implementation of an empirical sociological study by the author in 20162017. It was aimed the identifying features of social and professional orientations and student plans. The study covered 544 students of the Kherson region higher educational establishments. The different types of 
universities, specialties and students are represented in a quota and proportional sample.

The full-time students of Kherson region higher education establishments were selected as the study direct object. The study subject was the professional orientation of students.

The general research purpose was to study the peculiarities of the Kherson region students' professional orientations in order to identify the main areas improvement of the youth professional orientation work system in the region.

Just this research allows to solve a range of problems related to the definition of students' professional choice as:

- to establish the reasons of higher education obtaining and just the specialty;

- to outline the influence of different social agents on the students' professional

- orientation;

- to identify the attitude to the education quality;

- to identify factors of educational establishment choosing;

- to identify contradictions in obtaining a profession;

- to outline the chances of getting a job;

- to study the professional plans of graduate students from their orientation to

- work by specialty point of view;

- to find out the factors that influence the particular job choice;

- to identify the factors that determine the students' professional choice;

First of all, we have identified the reasons why students choose the specialties they are studying. The research shows that among the most attractive aspects of the chosen profession, students note the following: the prestige of the profession is $45.1 \%$, the creative nature of the work is $41.6 \%$, and the broad range of communication is $40.3 \%$. It should be noted that high wages are on the fifth place $-32.4 \%$. That can be said about the dominance of socially-oriented values when selecting a particular profession without the real situation on the labor market (only $16.4 \%$ of respondents pointed "easy to find work in the specialty").

The study results indicate that the greatest influence on students' choice has closest environment - parents and relatives $(59.3 \%)$. In addition, the influence of is increasing (39.3\%). At the same time, schools 
and centers of professional guidance have a much less influence (23\% and $16.5 \%$ appropriately).

This shows that in the absence of a full-fledged state professional guidance system, presented by educational and public institutions working with young people, the formation of professional youth benefits occurs spontaneously, without real trends in the labor market, mainly within the family. The emotional destiny is significantly serious in the future profession choice, characterized by media influence level.

Thus, this confirms the need of systematic work with youth at the early stage of its professional formation to ensure its effective entry into working life, taking the trends of socio-economic development of society and a specific region. An average family is almost unable to solve this problem independently.

According to our research, most parents of students have a high educational level (higher education $-38.7 \%$, secondary specialty $46.5 \%$, only $5.9 \%$ have a full secondary education). These are the persons who predominate in the technical and creative intelligentsia, civil servants, and entrepreneurs who occupy a sufficiently high position in their profession (47.4\% are heads of different levels in the organization or private entrepreneurs, $18.3 \%$ are specialists, $29,8 \%$ - the working class).

It is clear that these people have both developed motivation and more financial capacity, which allows to give their children higher education (even paid education). Thus, studying at universities can be considered as a mechanism for the parents' social status transfer to children and "vocational guidance" for higher education obtaining as a copy of the parents' life model, which is typical for families with a high social status.

Certain interest is the students' attitude to the quality of education. Among the reasons for the dissatisfaction with the level of education noted the following: lack of qualified teaching staff $-38.2 \%$, lack of fulltime internship at the enterprises $-32.6 \%$, unsatisfactory material and technical base $-25.3 \%$.

An effective combination of students' theoretical training and practical mastering of the profession during the educational process is a typical problem for Kherson as well as the whole country in our opinion. Higher school today does not fully perform its assigned function training of highly skilled professionals for the national economy. It also does not provide training in the social experience necessary to compete effectively in the labor market. 
According to our research, in the process of choosing a university, respondents were influenced by the following factors: the advice of relatives and friends $-32.6 \%$, high prestige of the university $-22.2 \%$, accident and coincidence $-16.8 \%$.

It is important to analyze the reasons that affect the attractiveness of universities. Thus, higher education attracts students with the opportunity to "obtain the necessary for professional activity knowledge" (73.4\%), "to reveal their intellectual qualities" (61.2\%), "to receive a higher education diploma" (58.5\%), as well $39.6 \%$ of respondents noted the possibility of interesting communication. This gives rise to talk about intellectual and pragmatic motivation of students for their studies at universities, the result of which must be both objective (diploma) indicators and subjective (specific knowledge) indicators, which together give some competitive advantages in the labor market.

However, some of these factors are not enough to be a competitive specialist. As our research shows, $40.6 \%$ of the polled students are forced to make extra money in their free time. At the same time for $16,9 \%$ - it is an opportunity to get a professional experience which is do necessary for successful employment.

The combination of study and work is a widespread practice for most of today's Ukrainian students. For $85.4 \%$ of the number of working students - it is necessity earnings for different needs. It is mainly forced employment and it is related to the need to keep oneself in the training period. For many students, extra earning is relevant just as a means of paying tuition (the data said $-64.5 \%$ of students study on a commercial basis).

It should be noted that $39.3 \%$ of students work more than 20 hours a week, $30.6 \%$ up to $10-20$ hours. These figures generally indicate a rather large employment of working students. Of course, this can not but affects their success and professional training. However, only $26.7 \%$ of respondents felt that employment negatively affects their performance, and $54.9 \%$ said no effect, and $18.4 \%$ of students believe that their secondary occupation positive impact on performance. In this case, $50.3 \%$ of students associated part-specialty with the major at university and $13.5 \%$ of students are working to get more ideas about the profession in practice. This fact is evidence of a "compensatory" function of secondary employment, which allows a student, in a poorly organized educational process, to acquire the professional knowledge and skills necessary for successful work. 
Therefore, we tried to identify the existing contradictions in professional plans of students, causing expression of supply and demand imbalance in certain type of human resources.

So, in general, $46.5 \%$ of students want to work in the specialty ( $18.1 \%$ would not like), while $10.3 \%$ would like to continue their studies in the chosen specialty. At least $18.1 \%$ of respondents are aware that they will not work in their specialty, that is, almost one of five students are in vain gaining knowledge of their profession, because their subsequent work will not use them. At the same time, these students spend their material and time resources irrationally, what can negatively affect their social capital formation.

In charge of the chances to find a job in the specialty after graduation, $53.7 \%$ of which there is a chance, $31.3 \%$ said that the chances are small, and $1.2 \%$ noted item "virtually no chance". Thus for successful employment, according to students, we must first have: real knowledge, skills and abilities $(62.3 \%)$, the labor market need in this profession $(59.7 \%)$, experience $(58.5 \%)$.

Guaranteed job will have $18.7 \%$ of respondents, $27.7 \%$ of students said that no and $53.6 \%$ could not answer the question. This indicates that the employment problem is students directly. In addition, the hypothesis of no interaction between higher education establishments and manufacturing organizations in the field of training is confirmed. That is in spite of the fact that employers have a need for qualified specialists, but they do not do specific university orders.

According to the results of the survey, the loss of confidence in existing institutions by the students regarding the ability to find a job in a specialty was confirmed (only $21.5 \%$ of the students counted on the help of the recruiting agencies). Given the complexity of finding a job related to lack of work experience, competition in the labor market, getting work is a top priority for the graduate. According to the results of the survey, the loss of confidence in existing institutions by the students regarding the ability to find a job in a specialty was confirmed (only $21.5 \%$ of the students counted on the help of the recruiting agencies). Given the complexity of finding a job related to lack of work experience, competition in the labor market, getting work is a top priority for the graduate. At the same time, as our study shows, student youth is oriented not on the possibility to work in a specialty with the purpose of 
employment, but on the socio-occupational benefits provided by a potential organization-employer.

Research shows that students focus on factors such as high wages (79.8\%), prospects for career growth $(76.5 \%)$, creative nature of work (46.9), social benefits and guarantees that is provided by the organization $(38,2 \%)$, the prestige of the organization $(34,9 \%)$. Only $27.1 \%$ chose to work in a specialty. This fact may indicate that the student during a job search is oriented towards stable organizations where well-paid work and career prospects are in progress, whereas professional specialization is of secondary importance.

If we analyze the level desired monthly payment, then $41.1 \%$ of students expect wages to 5,000 thousand UAH., and only $12.4 \%$ - from 7000 thousand UAH. Therefore, in general, we can diagnose the objective level of student's desired wages. Importantly, almost half of students $(49.1 \%)$ chose to work in state enterprises, $22.3 \%$ of students want to work for private enterprises and only $1.8 \%$ - in social organizations.

In other words, the results confirm that work in a private enterprise in a market economy is risky in terms of possible non-compliance by the employer with the norms of labor legislation, lack of social guarantees, uncertain prospects for personal professional development. So:

- most of the students targeted for "fashionable" professionals without their own abilities to the profession, interests;

- when choosing the future profession, young people are guided primarily thought of family members and relatives, while school and vocational guidance centers slightly influence the choice of future students;

- there is some emotion when choosing a specialty in higher education, as evidenced by significant influence of media on youth vocational guidance;

- in choosing a particular specialty, young people are guided primarily by factors such as prestige, creative professions, as well as the possibility of a wide range of communication;

- $40,6 \%$ of students are forced to work, the reason is the need for financial independence, as well as the desire to gain experience in the specialty;

- only $46.5 \%$ of students plan to work in the specialty after graduation (10.3\% want to continue their studies in the field); 
- every fifth student makes an irrational professional choice because he is not focused on work after a graduate degree;

- most students will not have a guaranteed post-graduate job, and when looking for a job they are focused mainly on self-help or help from friends (while the focus on employment assistance and recruitment agencies is not significant);

- in determining the future place of work, the key factors for students are high wages, career prospects, interesting work, social guarantees and prestige of the organization, while the opportunity to work in a specialty is of secondary importance;

- almost half of students want to work at enterprises of state ownership.

\section{CONCLUSIONS}

Now we can conclude that the social environment of a higher educational establishment is a powerful factor in the students' professionalization. It is the process of higher education obtaining that can be considered as an important contribution to a future specialist capitalization. This is confirmed by the findings of research on students' professional orientation of Kherson universities.

The social and cultural environment of higher education establishments creates all conditions for raising the level of students human capital in different fields contributes to the formation of future specialist critical thinking and develops the ability to use the acquired knowledge.

However, we can state that the analysis made it possible to find out that in the process of professional choice and professional orientation, which occupy a significant place in the modern system of training skilled personnel in Ukraine, there are a number of shortcomings. They are mostly derived from the general culture of society, as they are the results of the transformations of the values and normative orientations of modern society.

Today the prestige of the profession is not associated with its social value, but with the level of income that relevant professional activity provides. Everything mentioned above causes some deformation of labour orientations and professional values of future specialists. 
In addition, a basic requirement of modern employers is the need to ensure a higher level of professional adaptation to performing their professional functions. Under such circumstances, the only way to satisfy the current requirements for future employees is their social adaptation (as an ideal condition - their socialization) to future professional careers. Usually responsibility for the unsuccessful integration process is put on the social institution of education that does not provide sufficient conditions for the implementation of professional opportunities of young people (giving substandard knowledge, does not provide the quality of practice, etc.), prevents their selfrealization, thus contributing to its social exclusion.

The process of unsuccessful professional socialization and adaptation, which may result in a process of social exclusion, also deserves careful research attention. In this case, the appropriate exception can occur not at public, but at the professional level, which encourages young people to move away from the professional activities of a certain kind imitating professional search, or to attempt to put in other professional community (both occur fairly often). In this context, the general cultural capital of a society is gaining momentum. It will ensure the transformation of the value and regulatory structure of its members in accordance with the realities of social development. The last thesis is particularly relevant in the field of students' preparation for work.

\section{SUMMARY}

The article is devoted to the actual problem of professionalization of future graduates of higher education establishment. It is noticed, the low level of specialists' competitiveness and the necessity of their rapid integration into the corresponding profile of economic activity conditions predetermine the need for a radical revision of the system itself. The multidimensional nature of the problem determines a wide range of researches, including related to the problems of youth socialization, its cultural formation, capitalization of acquired knowledge, and also related to the analysis of the contemporary value and normative status of native students. This problem arises in two aspects: ontological and epistemological. Therefore, the research relevance of the professional development and formation process is a simultaneous study of the individuals' capitalization selfish goals mechanism implementation and 
adaptive mechanisms of effective integration into the labor process' changing conditions. In fact, there is a public need to find out the possible variations in the process of professional formation and their reduction in accordance with the specific social and productive conditions of the future specialist's functional duties. The above creates the formative and implementing preconditions for the specific social programs and projects aimed to intensify the professionalization process in the higher education establishment's social environment at different levels, and is also a significant factor of the future professional's capitalization. Stated that the period of transformation occurred fundamentally new situation in which young people make their professional choices based on unsteady occupational structure, lack of job security and the need to compete in the labor market. The above imposes a significant impact on professional choice logics.

\section{REFERENCES}

1. Словник української мови: в 11 томах. - Том 8, 1977. C. 332.

2. Душков Б.А., Королев А.В., Смирнов Б.А. Энциклопедический словарь: Психология труда, управления, инженерная психология и эргономика / Б.А. Душков, А.В. Королев, Б.А. Смирнов. - «Академический проект, Деловая книга», 2005. - 848 с.

3. Дюркгейм Э. Социология. Ее предмет, метод, предназначение / Пер. с фр., составление, послесловие и примечания А.Б. Гофмана.- М.: Канон, 1995.- 352 с.- (История социологии в памятниках), с. 34.

4. Рюль В.О. Дослідження феномену соціалізації в наукових концепціях розвитку особистості / В.О. Рюль // Науковий вісник Ужгородського університету : Серія: Педагогіка. Соціальна робота / [редкол.: Козубовська І.В. (гол. ред.) та ін.]. - Ужгород: Видавництво УжНУ «Говерла», 2011. - Вип. 23. - С. 150-154. Бібліогр.: С. 154 (18 назв).

5. Профессиональные группы: динамика и трансформация / Под ред. В.А. Мансурова. - М.: Изд-во Института социологии РАН, 2009. -419 c.

6. Сорокин, Питирим Александрович. Человек. Цивилизация. Общество / Питирим Сорокин; [Общ. ред., сост. и предисл., с. 5-24, А.Ю. Согомонова]. - М. : Политиздат, 1992. - 542 с. 
7. Профессиональные группы: динамика и трансформация / Под ред. В.А. Мансурова. - М.: Изд-во Института социологии РАН, 2009. - 419 c.

8. Парсонс Т.О социальных системах / Под ред. В.Ф. Чесноковой и С.А. Белановского. - М.: Академический проект, 2002. C. 350-351.

Information about the author: Shaposhnykova I. V. Doctor of Sociological Science, Dean of the Social and Psychological Faculty, Kherson State University 27, Universytetska str., Kherson, 73000, Ukraine 